\title{
Corrigendum: Thioreductase- Containing Epitopes Inhibit the Development of Type 1 Diabetes in the NOD Mouse Model
}

\author{
Elin Malek Abrahimians ${ }^{1,2}$, Luc Vander Elst ${ }^{1,2}$, Vincent A. Carlier ${ }^{1,2}$ \\ and Jean-Marie Saint-Remy ${ }^{1,2 *}$ \\ ${ }^{1}$ Center for Molecular and Vascular Biology, University of Leuven, Leuven, Belgium, ${ }^{2}$ ImCyse SA, Leuven, Belgium
}

Keywords: type 1 diabetes, NOD mouse, cytolytic CD4 ${ }^{+}$T cells, antigen-specific, MHC class II epitopes

\section{A corrigendum on}

Thioreductase-Containing Epitopes Inhibit the Development of Type 1 Diabetes in the NOD Mouse Model

by Malek Abrahimians E, Vander Elst L, Carlier VA, Saint-Remy J-M. Front Immunol (2016) 7:67. doi: 10.3389/fimmu.2016.00067

\section{OPEN ACCESS}

Edited and Reviewed by: Denise Doolan, James Cook University, Australia

*Correspondence: Jean-Marie Saint-Remy jean-marie.saint-remy@kuleuven.be

Specialty section:

This article was submitted to Vaccines and Molecular Therapeutics, a section of the journal Frontiers in Immunology

Received: 04 April 2018 Accepted: 27 June 2018 Published: 09 July 2018

Citation:

Malek Abrahimians E, Vander Elst L, Carlier VA and Saint-Remy J-M (2018) Corrigendum: Thioreductase-

Containing Epitopes Inhibit the Development of Type 1 Diabetes in the NOD Mouse Model.

Front. Immunol. 9:1600. doi: 10.3389/fimmu.2018.01600
In the original article, there was an error in the wording concerning the production of cytokines.

A correction has been made to the section Results, Subsection CCGAD65 Peptide Elicits CD4+ T Cells with a Unique Phenotype and Cytolytic Properties, Paragraph 2:

The phenotype at resting state, 14 days after last stimulation with CCGAD65-loaded APCs, was $\mathrm{CD}^{+} \mathrm{CD} 4^{+} \mathrm{CD} 8^{-} \mathrm{CD} 25^{+} \mathrm{CD} 44^{+} \mathrm{CD} 62 \mathrm{~L}^{-} \mathrm{CD} 127^{-} \mathrm{CD} 27^{-} \mathrm{CD} 28^{-}$, indicative of an effector memory phenotype. Some cells were positive for T-Bet and/or GATA-3, but all were negative for Foxp3. The production of cytokines was essentially Il- 4 and low IFN- $\gamma$. This distinct phenotype was conserved even when cells were repeatedly stimulated in vitro with the WTGAD65 peptide, suggesting a terminal differentiation. By contrast, the phenotype expressed by $\mathrm{CD} 4^{+} \mathrm{T}$ cells generated in a similar manner from mice immunized with the WTGAD65 peptide was $\mathrm{CD} 3{ }^{+} \mathrm{CD} 4^{+} \mathrm{CD} 8{ }^{-} \mathrm{CD} 25^{+} \mathrm{CD} 44^{+}$ $\mathrm{CD}^{2} 2 \mathrm{~L}^{-} \mathrm{CD} 127^{\text {high }} \mathrm{CD} 27^{\text {high }} \mathrm{CD} 28^{-}$(Figure 2B; Figures S3 and S4 in Supplementary Material). Altogether, this indicates that cells generated with a thioreductase-containing peptide are terminally differentiated effector $\mathrm{T}$ cells with a memory phenotype.

The authors apologize for this error and state that this does not change the scientific conclusions of the article in any way.

The original article has been updated.

Conflict of Interest Statement: The authors declare that the research was conducted in the absence of any commercial or financial relationships that could be construed as a potential conflict of interest.

Copyright (c) 2018 Malek Abrahimians, Vander Elst, Carlier and Saint-Remy. This is an open-access article distributed under the terms of the Creative Commons Attribution License (CC BY). The use, distribution or reproduction in other forums is permitted, provided the original author(s) and the copyright owner(s) are credited and that the original publication in this journal is cited, in accordance with accepted academic practice. No use, distribution or reproduction is permitted which does not comply with these terms. 